\title{
The Contribution of Environmental Impact Assessment Studies to the Flora Biodiversity in Sudan
}

\author{
Osman M. M. Ali, Mohamed F. Idris \\ Institute of Environmental Studies, Khartoum, Sudan \\ Email:osmirghani@yahoo.co.uk
}

How to cite this paper: Ali, O.M.M. and Idris, M.F. (2016) The Contribution of Environmental Impact Assessment Studies to the Flora Biodiversity in Sudan. Journal of Environmental Protection, 7, 1707-1718. http://dx.doi.org/10.4236/jep.2016.712138

Received: May 11, 2016

Accepted: November 4, 2016

Published: November 7, 2016

Copyright $\odot 2016$ by authors and Scientific Research Publishing Inc. This work is licensed under the Creative Commons Attribution International License (CC BY 4.0).

http://creativecommons.org/licenses/by/4.0/

(c) (i) Open Access

\begin{abstract}
Environmental Impact Assessment Studies (EIA) for four developmental projects were chosen for this study viz-a-viz., oil and gas, river diversion, hydropower and gold mining. The EIA studies for these activities have been conducted in three different ecological regions: the flood region in the former southern Sudan, low rainfall Savannah and desert region. Trees, shrubs and herbaceous species were identified and recorded in each region. Species encountered for the first time, endangered, invasive and increasers were also reported. The EIA studies have produced lists of natural flora in areas which were difficult to access without the EIA missions. During the EIA study for Jonglei Canal project the new mono specific genus Suddia sagitifolia was discovered in the flood region as the only endemic aquatic plant in Sudan. Within the same region, the smallest floating plant in Sudan (Wollfia hyaline) was reported. The critically endangered "Argon Palm" (Medemia argun) was encountered in the Nubian Desert of the Red Sea State during a gold mining EIA study. The Seha (Belpharis persica), not reported to exist in desert conditions, has been found in the Great Desert west of the Nile during an EIA study for Kajbar Hydropower project. The paper calls for the publication of the above findings and highlights the need for further detailed studies in order to enhance knowledge of the Sudanese biodiversity status.
\end{abstract}

\section{Keywords}

Environmental Impact Assessment, Flora, Biodiversity, Endangered

\section{Introduction}

Sudan is endowed with many ecological zones; they extend from the desert and semidesert in the north to the low rainfall woodland savannah in the south. The ecological 
variability made Sudan rich in plants biodiversity encompassing many agricultural crops, fruit trees and natural vegetation of woody and herbaceous plants.

The flora diversity in the natural ecosystems supplies the country population-nomadic pastoralists, agro-pastoralists and urban communities with a wide range of services and values such as:

- Source of food and feed for humans and animals;

- Maintenance of the gaseous quality of the atmosphere;

- Mitigation of global warming via contribution in carbon sequestration;

- Protection of watershed areas and buffering against floods impacts;

- Provision of medicinal and aromatic products;

- Contribution in soil formation;

- Protection and maintenance of the productive capacity of the lands by reducing water and wind force actions; and

- Participating in cultural and aesthetic values.

However, the natural plants are under continuous threats emanating from, inter alia:

- Overgrazing;

- Cutting for cropping, fuel and building;

- Desertification and climate change; and

- Land preparation for development projects.

The situation is aggravated by lack of a complete, authentic and updated list of the natural flora. Lack of experts, funds and the presence of some of these plant communities in remote, inaccessible regions have exacerbated the grave situation. It is for the latter constraint that environmental impact assessment studies have come to play a significant alleviating role.

EIA is a systematic process to identify, predict and evaluate the environmental effects of proposed actions and projects. The process also proposed appropriate mitigation measures to offset significant adverse impacts of the proposed projects [1]. To fulfil the mandate of an EIA and for its objectives to be materialized, the environment where the project is going to be constructed and operated, or where its impacts could reach, the original environment has to be studied. Such a study which entails the documentation of present status of the physical and biological environmental components is called the baseline study. The geology, hydrology, (surface and ground water), meteorology, air quality, soil, vegetation, wildlife, land use and socio-economic aspects are all components of the baseline part of the EIA.

\section{Material and Methods}

Four developmental projects were chosen for this study viz-a-viz., oil and gas, hydropower, river diversion and gold mining. The EIA studies for these activities have been conducted in three ecological regions: the flood region in the former southern Sudan, low rainfall Savannah and in the desert region, respectively.

Qualitative and quantitative analyses of the vegetation have been carried out in each region selected sites. The plants encountered were qualitatively described into trees, 
shrubs and herbaceous species. The flora was identified and recorded in each region. Species encountered for the first time, new and endangered species were also reported. The identification resulted in the preparation of a list of grasses, other herbs (forbs) on the herbaceous layer, as well as trees and shrubs of the woody layer in the project area. Species which were not identified in the field were photographed, samples collected and later on identified through taxonomy books and by consulting experts. Quantitative estimates were conducted for the woody species using a quadrate $(20 \mathrm{~m} \times 20 \mathrm{~m})$ to get the density of trees and shrubs in the area. Inventory of both qualitative and quantitative parameters were done along selected transect lines covering the project area. Other observations on the sampling points and along the selected transects such as soil type and condition, topography and land use were also recorded. GPS was used to document the studied flora together with photography with a digital camera. Tables 1-3 show the species lists of the flora in the EIA areas of studied projects.

\section{Results and Discussions}

\subsection{Provision of Recent/Updated Plant Lists}

The first list is obtained from an EIA study for an oil exploration project in Block 5B in the swamps of the upper stretch of the White Nile in the former southern Sudan WNPOC [2].

The list in Table 1 will have to be looked upon in the light of the paucity of aquatic plants lists [3].

The second list (Table 2) describes the flora in the desert zone obtained during an EIA study for the proposed Kajbar Hydropower project [4]. The plants were classified into trees, shrubs, grasses and forbes.

The third list of plants (Table 3) was assembled during an EIA study tour for an oil development project in Western Kordofan State where a pipeline was proposed to transport crude oil [5].

The area in which the proposed oil pipeline crosses is known for its good vegetation cover especially during the rainy season. Harrison and Jackson [6] classified the vegetation of this area as Combretum glutinosum-Dalbergia melanoxylon-Albizia amara Savannah woodland as sub-division of the low rainfall woodland savannah on sand. This sub-division occurs in areas of rainfall ranging between $450-600 \mathrm{~mm} /$ year. The dominant woody species were mostly broad-leafed non-thorny such as: Combretum glutinosum, D. melanoxylon, A. amara, Guirea senegalensis, Sclerocarya birrea, Commiphora africana, Lannea humilis, Terminalia laxiflora, Terminalia brownii, Dalbergia melanoxylon and Adansonia digitata. Currently C. africana and L. humilis are decreasing due to their intensive use by the pastoralists and agro-pastoralists for robes making, buildings materials etc. while $G$. senegalensis, C. glutinosum and Terminalia spp. are increasing due to less destruction. Dichrostachys cinerea is found to increase along animal tracks, night camps and roads sides. Dalbergia melanoxylon is severely decreasing due to the high run-off, on the bare areas around the small savannah deciduous tree causing root system desiccation and also the human intensive use of the wood. 
Table 1. Aquatic plants of the flood region in block B 5.

\begin{tabular}{|c|c|c|}
\hline No & Botanical Name & Family \\
\hline 1 & Azolla nilotica & Azollaceae \\
\hline 2 & Cyclosorus interruptus & Azollaceae \\
\hline 3 & Cyperus papyrus & Cyperaceae \\
\hline 4 & Cyperus mundii & Cyperaceae \\
\hline 5 & Phragmites karka & Poaceae \\
\hline 6 & Vosia cuspidate & Poaceae \\
\hline 7 & Echinochloa stagnina & Poaceae \\
\hline 8 & Echinochloa pyramidalis & Poaceae \\
\hline 9 & Oryza barthii & Poaceae \\
\hline 10 & Oryza longstminata & Poaceae \\
\hline 11 & Hyparrhenia rufa & Poaceae \\
\hline 12 & Seteria incrassata & Poaceae \\
\hline 13 & Suddia sagitifolia ${ }^{*}$ & Poaceae \\
\hline 14 & Vetiveria nigritana & Poaceae \\
\hline 15 & Typha domingensis & Typhaceae \\
\hline 16 & Luffa cylidrica & Cucurbitaceae \\
\hline 17 & Ipomoea carca & Concolvulaceae \\
\hline 18 & Ipomoea aquatica & Concolvulaceae \\
\hline 19 & Vigna nilotica & Papilionaceae \\
\hline 20 & Trapa natans & Trapaceae \\
\hline 21 & Eichhornia carssipes & Pontederiaceae \\
\hline 22 & Nymphaea lotus & Nymphaceae \\
\hline 23 & Nymphaea caerulea & Nymphaceae \\
\hline 24 & Nymphaea micrantha & Nymphaceae \\
\hline 25 & Pistia stratiotes & Araceae \\
\hline 26 & Lemna gibba & Lemnaceae \\
\hline 27 & Walffia hyaline & Lemnaceae \\
\hline 28 & Polygnoum pulchrum & polygonaceae \\
\hline 29 & Ceratophyllum demersum & Ceratophyllaceae \\
\hline 30 & Melanthera scadens ssp. madagasciensis & Astraceae \\
\hline 31 & Cissus ibuensis & Ampelidaceae \\
\hline 32 & Hyphaene thebaica & Palmaceae \\
\hline 33 & Barassus aethiopium & Palmaceae \\
\hline
\end{tabular}

${ }^{\star}$ Nomen novum.

The previous ground cover was mentioned to be composed of Brachiarra xantholeuea, Eragrostis termula, Cenchrus biflorus, Aristidapallidac, Andropogan gayanus, Pennsetium pedicellatum, Blepharis linariifolia, Zornia glochidiata and Monechma hispidum. Currently, C. biflorus (Huskaneit) and B. linariifolia were not observed and the 
Table 2. Natural trees and shrubs in Kajbar area, northern Sudan natural grasses and other herbs.

\begin{tabular}{|c|c|}
\hline Botanical Name & Family \\
\hline Aerva javanica & Amarnthaceae \\
\hline Abutilon spp. & Malvaceae \\
\hline Demostachya cynosuroides & Poaceae \\
\hline Senna italica & Caesalpiniaceae \\
\hline Haplophyllum tuberculatum & Rutaceae \\
\hline Polygonum setulosum & Polygonaceae \\
\hline Tephrosia apollinea & Fabaceae \\
\hline Fagonia critica & Zygophllaceace \\
\hline Indigofera ablongifolia & Fabaceae \\
\hline Euphorbia aegyptiaca & Euphorbiaceae \\
\hline Cynadon dactylon & Poaceae \\
\hline Daicanthium annulatum & Poaceae \\
\hline Rhynchosia minima & Fabaceae \\
\hline Blepharis persica & Acanthaceae \\
\hline Blepharisl inariifolia & Asteraceae \\
\hline Solanum incanum & Solanaceae \\
\hline Chrozaphora spp. & Euphorbiaceae \\
\hline Xanthium barsilicum & Asteraceae \\
\hline Crotalaria thebica & Fabaceae \\
\hline Farsetia spp. & Cruciperae \\
\hline Panicum turgidum & Poaceae \\
\hline Datura stramonium & Solanaceae \\
\hline Citrullus colocynthis & cucurbitaceae \\
\hline Boerhavia repens & Myctaginaceae \\
\hline Cyperus rotundus & Cyperaceae \\
\hline Cyperus spp. & Cyperaceae \\
\hline
\end{tabular}

people met confirmed their disappearance. List of the current natural vegetation in the project area is given in Table 3.

\subsection{Evidence of Sightings in Unrecorded Sites and Locations}

\section{Belpharis persica (Burm.f.) kuntze. Synonym: Belpharis edulis}

This is an annual woody herb, with spiny leaf margin of the family Acanthaceae. The green and dry plant is a very valuable camel fodder while sheep, goats and cattle relish the plant when green. It is found in the semi-desert ecological zones of Butana plain of eastern Sudan, Erkawit and khor Dahand in the Red Sea State [7]. It was not specifically 
Table 3. List of the natural vegetation in the area of the oil pipe line from Baleela to Um Adara. (a) Woody species, (b) Herbaceous species.

(a)

\begin{tabular}{|c|c|}
\hline Scientific name & Family \\
\hline Acacia nilotica & Leguminosae: Mimosoideae \\
\hline Acacia gerrarrdii & Leguminosae: Mimosoideae \\
\hline Acacia senegal & Leguminosae: Mimosoideae \\
\hline Acacia laeta & Leguminosae: Mimosoideae \\
\hline Acacia seyal & Leguminosae: Mimosoideae \\
\hline Acacia mellifera & Leguminosae: Mimosoideae \\
\hline Albizia amara & Leguminosae: Mimosoideae \\
\hline Anogeissus leiocarpus & Combretaceae \\
\hline Adansonia digitata & Bombacaceae \\
\hline Balanites aegyptiaca & Zygophyllaceae \\
\hline Calotropis procera & Asclepiadaceae \\
\hline Dalbergia melanoxylon & Leguminosae: Papilionoideae \\
\hline Dichrostachys cinerea & Leguminosae: Mimosoideae \\
\hline Guiera senegalensis & Combretaceae \\
\hline Maerua spp. & Capparaceae \\
\hline Sclerocarya birrea & Anacardiaceae \\
\hline Terminalia laxiflora & Combretaceae \\
\hline Ziziphus spina-christi & Rhamnaceae \\
\hline Combretum aculeatum & Combretaceae \\
\hline Combretum glutinosum & Combretaceae \\
\hline Combretum hartmannianum & Combretaceae \\
\hline Piliostigma reticulatum & Leguminosae: Caesalpinoideae \\
\hline Boswellia papyrifera & Burseraceae \\
\hline Cordia Africana & Boraginaceae \\
\hline Ipomoea cornea & Convolvulaceae \\
\hline Ficus spp. & Moraceae \\
\hline Commiphora africana & Burseraceae \\
\hline
\end{tabular}

(b)

\begin{tabular}{cc}
\hline Scientific name & Family \\
\hline Aristida mutabilis & Poaceae \\
Aristida pallidae & Poaceae \\
Andropogon gayanus & Poaceae \\
Abutilon spp. & Malvaceae \\
Brahiaria obtusiflora & Poaceae \\
\hline
\end{tabular}




\section{Continued}

\begin{tabular}{|c|c|}
\hline Eragrostis tremula & Poaceae \\
\hline Cassia tora & Leguminose: Caesalpinioideae \\
\hline Cassia mimosoides & Leguminose: Caesalpinioideae \\
\hline Setaria pallide-fusca & Poaceae \\
\hline Echinochloa colona & Poaceae \\
\hline Dactyloctenium aegyptium & Poaceae \\
\hline Pennisteum pedicellatum & Poaceae \\
\hline Corchorus spp. & Malvaceae \\
\hline Ipomeoa repens & Convolvulaceae \\
\hline Solanum dubium & Solanaceae \\
\hline Stylosanthes fruticosa & Leguminoseae: Papilinioideae \\
\hline Indigofera spp. & Leguminoseae: Papilinioideae \\
\hline Euphorbia spp. & Euphorbiaceae \\
\hline Cyperus spp. & Cyperaceae \\
\hline Brachiaria xantholeuca & Poaceae \\
\hline Euphorbia aegyptiaca & Euphorbiaceae \\
\hline Chloris spp. & Poaceae \\
\hline Zornia glochidiata & Leguminoseae: Papilinioideae \\
\hline Ctenium elegans & Poaceae \\
\hline Digitaria intecta & Poaceae \\
\hline Hyparrhenia confins & Poaceae \\
\hline Sesabania sesaban & Leguminoseae: Papilinioideae \\
\hline Oldenlandia senegalensis & Poaceae \\
\hline Sorghum lanceolatum & Poaceae \\
\hline Sporobolus marginatus & Poaceae \\
\hline Sporobolus festivus & Poaceae \\
\hline Elusine indica & Poaceae \\
\hline Sida cordifolia & Malvaceae: Malvoideae \\
\hline Hypostis cancellata & Acanthaceae \\
\hline Ipomoea aquatica & Convolvulaceae \\
\hline Acanthospermum hispidum & Asteraceae \\
\hline Hibiscus spp. & Malvaceae: Malvoideae \\
\hline Amaranthus spp. & Amaranthaceae \\
\hline
\end{tabular}

mentioned in the flora of the desert ecological zone. Long drought spells after germination may cause complete disappearance of the plant from the rangeland. At present the plant has disappeared from many grazing areas of Butana. There is only one area from 
which seed stock can be collected for regeneration (reseeding) which is Jebel Elmundra in the Butana plain, where stands of under-grazed plants are found due to limited resources of livestock drinking water. Light clay soils are suitable for germination and establishment of uncovered mature seeds.

During an EIA survey for the proposed Kajbar hydropower dam, Belpharis was found in one of the seasonal water courses draining into the western bank of the River Nile. This could be the first record of the species in the desert zone of Sudan (Figure 1 \& Figure 2).

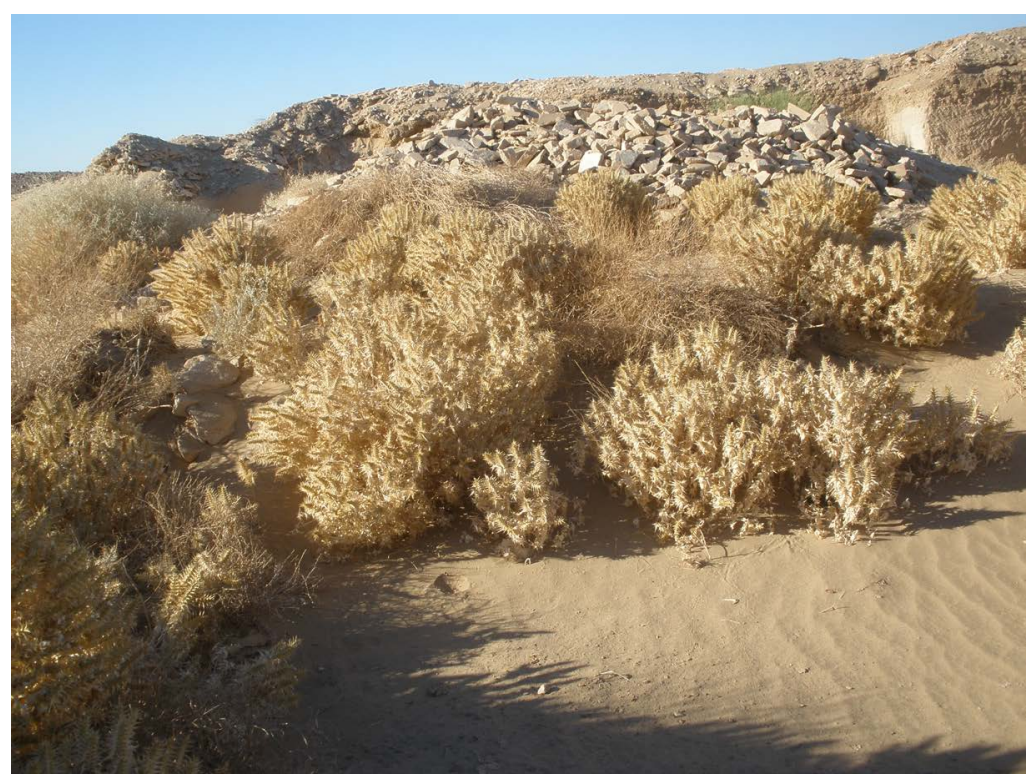

Figure 1. Belpharis persica in a dry seasonal wadi in Kajbar area (northern state).

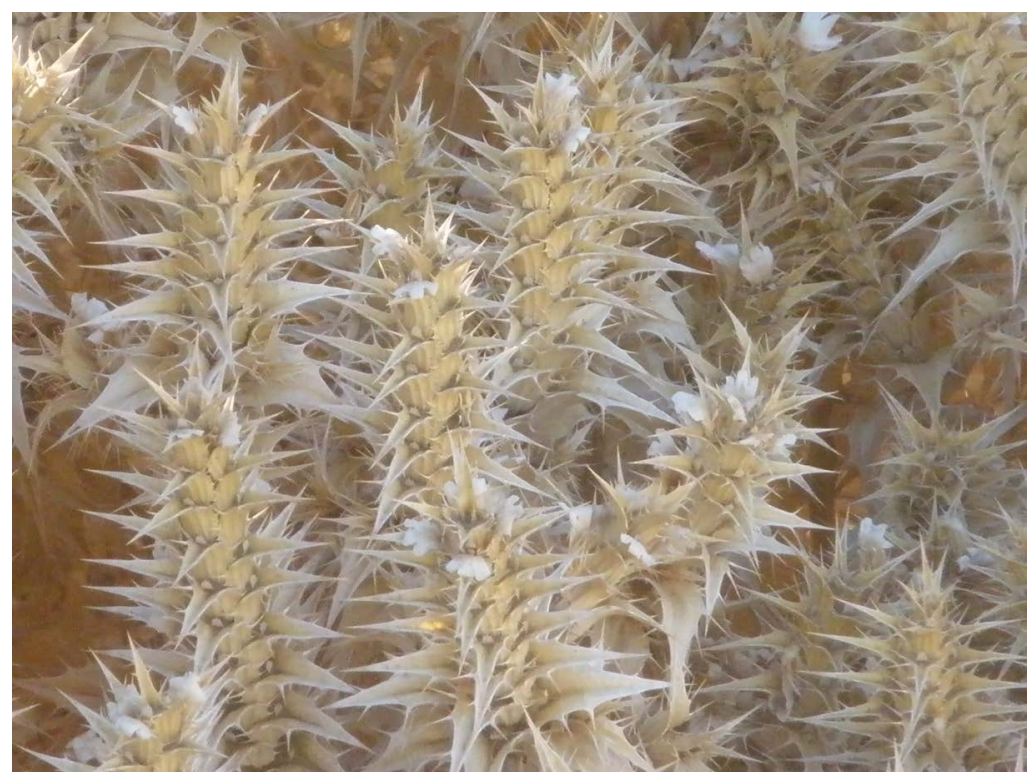

Figure 2. Close up of Blepharis persica. 


\subsection{Provision of New Information on Endangered Species}

Medemia argun (Martius) Wuttt. ex H. A. Wendi Family: Arecaceae (Figures 3-5).

Medemia is a monotypic genus endemic to the upper valley of the River Nile in Egypt and Sudan. Nowadays, there are only a few localities in which this palm is found, and in most cases the populations there consist of very few individuals. The Sudanese Nubian Desert east of the River Nile is the only region where the plant is now naturally growing. This region is so arid that consecutive years pass without any rain falling. Though the terrain is harsh with many rocky features, the Nubian Desert is characterized by a network of seasonal water courses that drain into and form the large WadiGabgaba. These wadis could run with flash floods coming from seasonal rainfall in the Red Sea Hills. According to the International Union for the Conservation of Nature (IUCN) Red list Category and Criteria [8], the "Argoun Palm" is critically endangered.

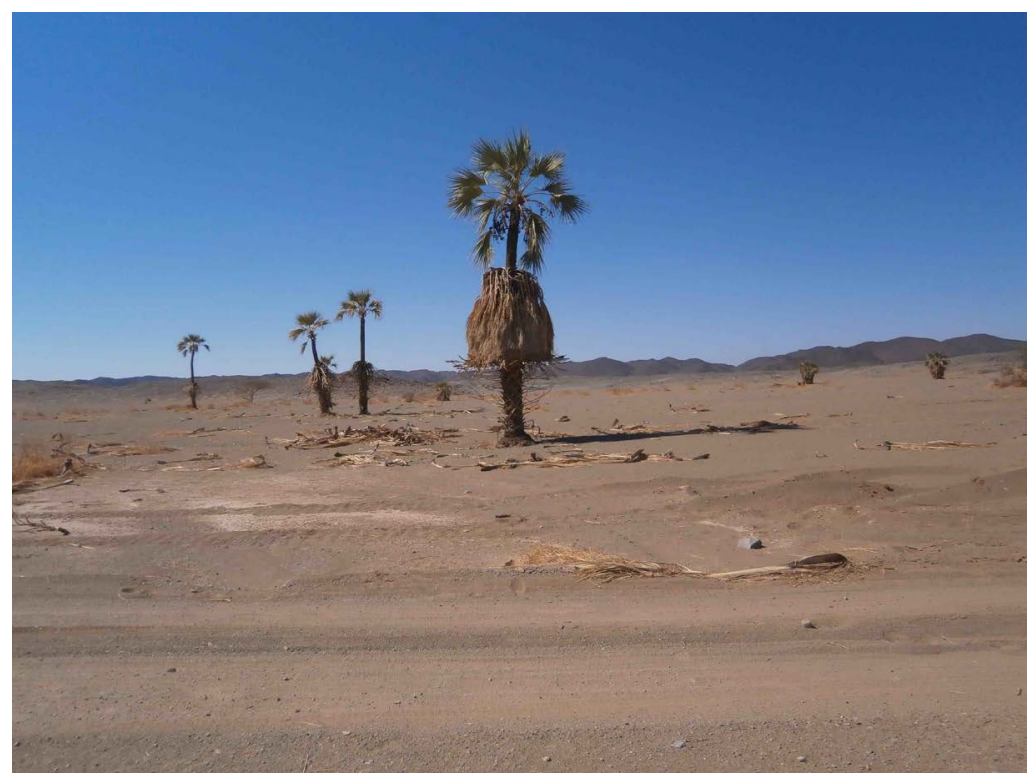

Figure 3. Argoun palm showing a skirt of dry leaves.

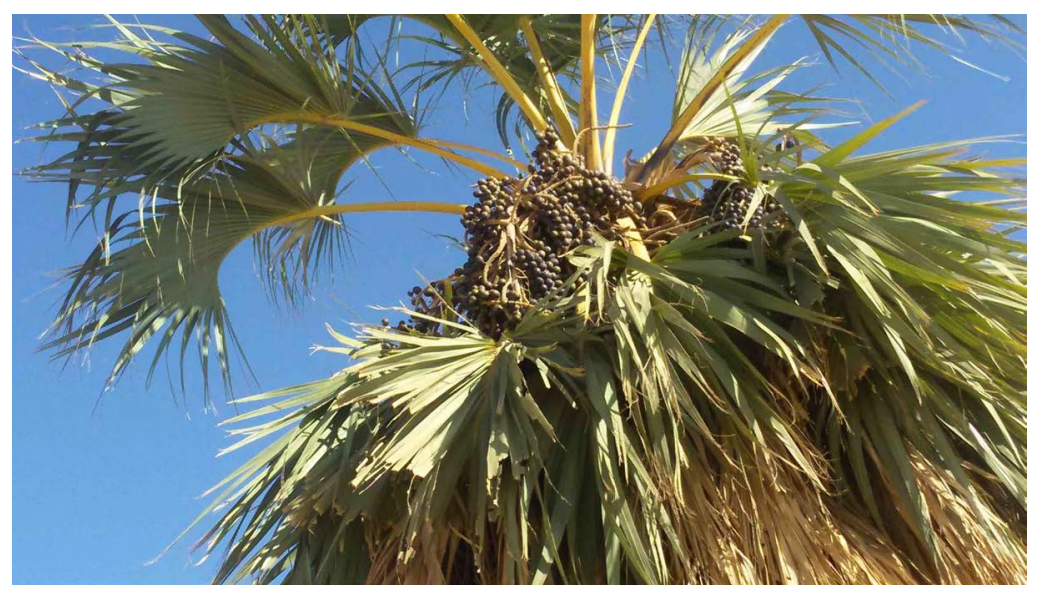

Figure 4. Argoun palm tree with a cluster of fruits. 


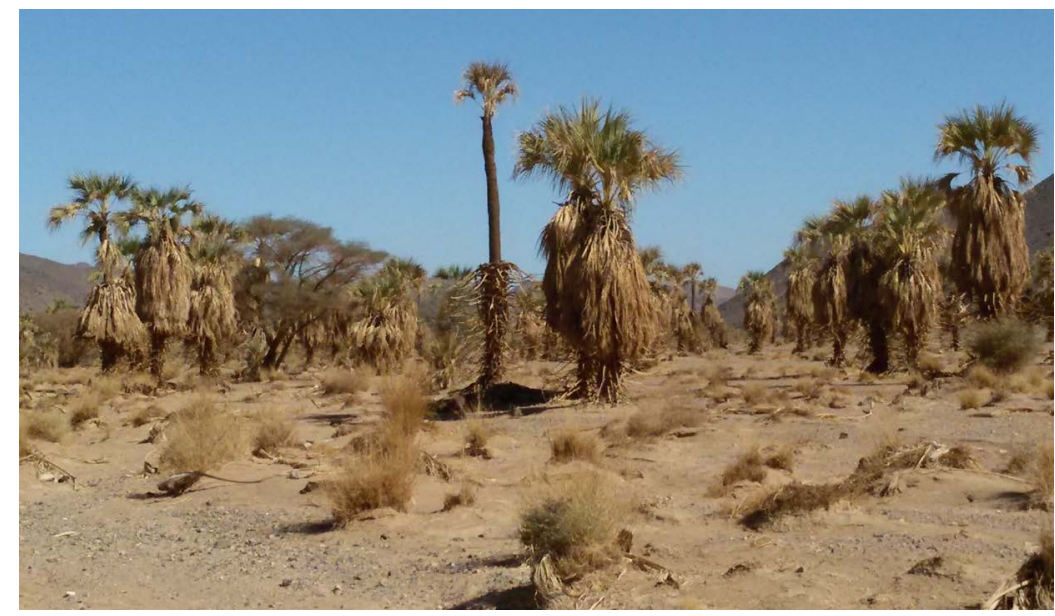

Figure 5. A dense population of Argoun palm.

During two visits to the eastern Nubian Desert in 2011 and 2015, several populations of Medemia have been encountered. The findings have manifested not only that Medemia still exists, but it inhabits many locations. Most striking is that the tree is in good condition and many fruiting trees and several young trees at different stages of growth have been encountered [9]. Nevertheless, the criterion upon which IUCN has categorized the Argoun palm as critically endangered-small and fragmented populations-is still valid.

\subsection{Discovery of New Species (Nomennovum)}

During a multidisciplinary expedition organized in 1979 by the Hydrobiological Research Unit (Later on amalgamated in the IES) of University of Khartoum to study the expected environmental and social impacts of the proposed Jonglei Canal in southern Sudan, a plant was observed growing in swamps at the joining of Bahr el Zeraf and a side lake. It was first taken to be a member of the Araceae family due to the sagitate shape of the leaf base. When several specimens were taken to Kew, London, it was discovered that the plant is not only a new species but a new genus of the poaceae (Graminae) family! It was aptly named Suddia sagitifolia. The discovery was considered as the declaration that Suddia sagitifolia is the only endemic aquatic plant in the Sudan (Figure 6) [10]. Endemic plants and animals are those that are unique to a specific geographic region. This makes them incredibly special and more vulnerable to extinction. Because they are only found in certain locations, they require special conservation efforts.

The plant was encountered by the author during a later field work mission in 2005 organized by the IES as part of an EIA study for Block 5B for the White Nile Petroleum Operating Company within Bahr el Zeraf Basin [2]. Very recently the same plant was found in some wetlands in Uganda and the plant was rated as a near endemic species. Nevertheless, the credit for this contribution of international dimension still remains to the EIA of seventies of the last century. Within the same region the smallest floating plant (Wollfia hyaline) in the former Sudan was also reported. 


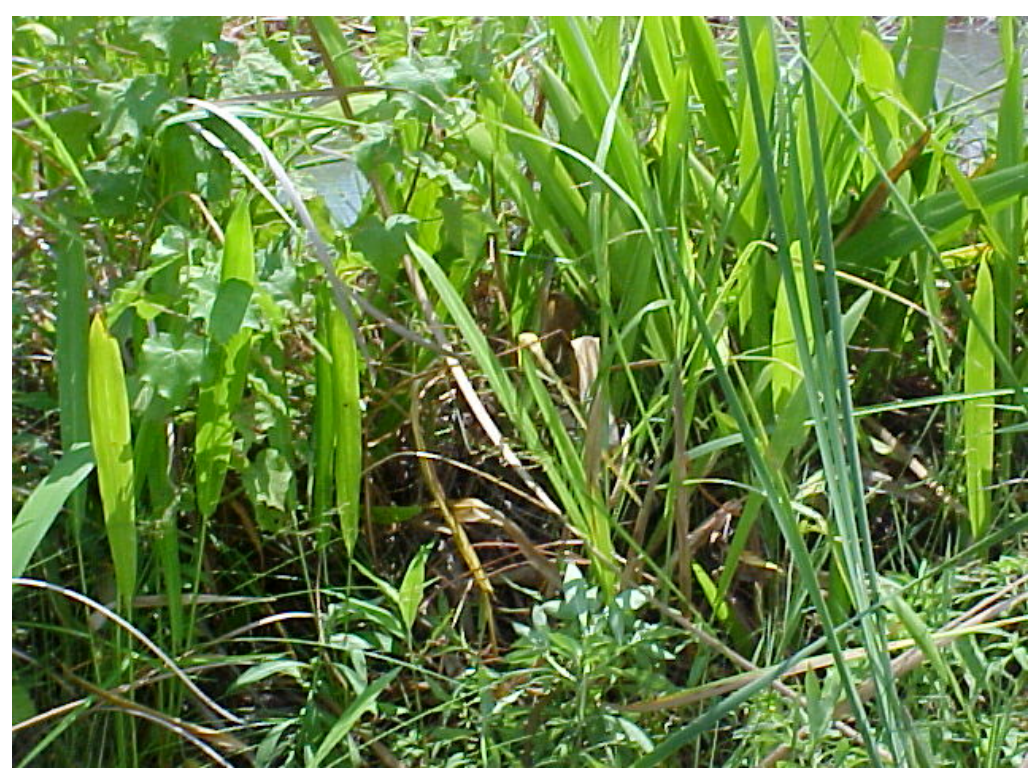

Figure 6. Suddia sagitifolia with bright green leaves in the former southern Sudan [2].

The available information on the distribution of flora on Sudan is old and limited. The EIA studies have availed valuable chances for the flora expert within the EIA team to visit many sites within Sudan. Some of these sites fall in regions which are otherwise inaccessible hadn't it been for the EIA missions. The lists are not exclusive yet useful for future monitoring and for providing a base to revise and update the flora list. The identification of the plants was not an easy task due to the paucity in taxonomy references as well as national taxonomists. So far the only available references are the three volumes of Andrews in the fifties of the last century [11] [12]. However, recently a significant contribution to alleviate this situation is the publishing of an annotated checklist on the plants of Sudan and South Sudan [13].

\section{Conclusions}

- Environmental Impact Assessment studies could be a valuable source of information in the field of biodiversity.

- The obtained lists could be a valuable baseline for future monitoring studies where changes due to natural and anthropogenic factors can be detected.

- The contribution could be many fold: in producing species list, in taxonomy update and in producing new information about species distribution.

- The studies revealed the paucity in endemic species in Sudan (only one).

\section{Recommendations}

- EIA reports should be used to document fauna as well.

- The documented lists should be used for future follow up and monitoring studies.

- EIA consulting companies need to be requested to adopt the most recent taxonomic nomenclature. 
- More research should be directed towards endemic and endangered species in Sudan.

\section{References}

[1] UNEP (2002) Environmental Impact Assessment Training Resource Manual. (Eds) B. Sadler and M. McCabe.

[2] White Nile Petroleum Operating Company (WNPOC) (2005) ESIA Report for Block B, Southern Sudan.

[3] Ali, O.M.M. (2009) The Aquatic Plants of Sudan. In Dumont, H.,Ed., The Nile: Origin, Environments, Limnology and Human Use. Springer Publisher, Germany, 479-494. http://dx.doi.org/10.1007/978-1-4020-9726-3_23

[4] Fichtner-UKCC (2009) Environmental Impact Assessment for Kajbar Hydropower Project.

[5] StarOil Petroleum Operation Company (2014) Crude Oil Pipeline from South Annajama EPF to the Landing Terminal of GNPOC Export Pipeline at Um Adara.

[6] Harrison, M.N. and Jackson, J.K. (1958) Ecological Classification of the Vegetation of the Sudan. Forest Bull No.2. (New Sereis): 1-45. Khartoum.

[7] Hassan M.H. (1974) An Illustrated Guide to the Plants of Erkawit. Khartoum University Press, Khartoum.

[8] IUCN (2010) Red List of Threatened Species. Version 2014.3.

[9] Ali, O.M.M. (2016) The Argun Palm, (Medemia argun), in the Eastern Nubian Desert of Sudan. PALMS, 60, 145-153.

[10] Renovate, S.A., Lock, J.M. and Denny, P. (1984) A Remarkable New Grass Genus for the Southern Sudan. Kew Bulletin, 39, 455-461. http://dx.doi.org/10.2307/4108589

[11] Andrews, F.W. (1950, 1953) The Flowering Plants of the Anglo-Egyptian Sudan. V. 1 \& II. T. Buncle \& Co. Arbroath, Scotland.

[12] Andrews, F.W. (1956) The Flowering Plants of the Sudan. V. III. T. Buncle \& Co. Arbroath, Scotland.

[13] Derbyshire, I., Kordofani, M., Farag, I., Candiga, R. and Pickering, H. (Eds.) (2015) The Plants of Sudan and South Sudan: An Annotated Checklist. Royal Botanic Gardens, Kew, United Kingdom.

Submit or recommend next manuscript to SCIRP and we will provide best service for you:

Accepting pre-submission inquiries through Email, Facebook, LinkedIn, Twitter, etc.

A wide selection of journals (inclusive of 9 subjects, more than 200 journals)

Providing 24-hour high-quality service

User-friendly online submission system

Fair and swift peer-review system

Efficient typesetting and proofreading procedure

Display of the result of downloads and visits, as well as the number of cited articles

Maximum dissemination of your research work

Submit your manuscript at: http://papersubmission.scirp.org/

Or contact jep@scirp.org 